\title{
On National Unified Graduation Examination for Ethnic Preparatory Education Program
}

\author{
Tuo Ya \\ Ethnic Education School \\ Beijing University of Posts and Telecommunications \\ Beijing, China \\ tuoyabupt@163.com \\ Xia Zengyan \\ Ethnic Education School \\ Beijing University of Posts and Telecommunications \\ Beijing, China
}

\author{
Zhu Jianping \\ Ethnic Education School \\ Beijing University of Posts and Telecommunications \\ Beijing, China \\ Yang Jingpeng \\ Ethnic Education School \\ Beijing University of Posts and Telecommunications
}

Beijing, China

\begin{abstract}
The purpose of this paper is to elaborate on the necessity, objectives, guidelines, potential problems and countermeasures of organizing National Unified Graduation Examination for Ethnic Preparatory Education Program. A questionnaire survey is conducted in four preparatory training institutions to get a general idea of the identification and acceptance degree from the faculty and preparatory students concerning launching National Unified Graduation Examination for Ethnic Preparatory Education Program. The results show that a majority of the student respondents identify with the positive wash-back effect of launching National Unified Graduation Examination, which will motivate them to work harder. Most teacher respondents take an affirmative attitude to the necessity, significance and positive roles of National Unified Graduation Examination for Ethnic Preparatory Education Program. These results support the idea that launching National Unified Graduation Examination for Ethnic Preparatory Education Program will be conducive to establishing a standardized, scientific and rigorous evaluation system so as to improve the overall quality of preparatory education.
\end{abstract}

Keywords-necessity; objectives; guidelines; potential problems; countermeasures

\section{INTRODUCTION}

Preparatory education program for ethnic college students, which lasts for one or two years prior to the four-year formal college education, is an important part of National Higher Education and an implementation of national preferential policy for ethnic minorities. Each year, tens of thousands of minority preparatory students are trained through the preparatory education program in such basic subjects as math, physics, Chinese language and English, etc, in order that they could be academically competent enough to go on with their formal college education.

However, it is an undeniable fact that preparatory education program for ethnic students has been faced with some problems in the past decades with respect to teaching management, teaching quality, curriculum design, faculty, hardware facilities and evaluation. Queries about the effectiveness and necessity of preparatory education program for ethnic college students have been heard from different sources.

To approach the problems mentioned above, the national functional department and administrative departments at different levels have been conducting surveys and investigations to probe into the necessity and practicability of organizing and launching National Unified Graduation Examination for Ethnic Preparatory Education Program. In May, 2015, a computer-based pilot National Unified Graduation Examination for Ethnic Preparatory Education Program was conducted in dozens of preparatory training institutions across the nation, and tens of thousands of ethnic preparatory students sat for the pilot examination, which paved a way for establishing a standardized, scientific and rigorous evaluation system so as to promote preparatory training institutions to attach greater importance to enhancing the level of scientific management, as well as improving teaching quality of preparatory education.

\section{THE NeCESSITY OF LAUNCHING NATIONAL UNIFIED GRADUATION EXAMINATION}

National Unified Graduation Examinations at different levels, such as at junior high school level and at senior high school level, have been carried out for decades and have turned out to be conducive in shaping advanced modern educational concepts, improving the software and hardware conditions for running a school, standardizing teaching management, enhancing the quality of education etc.. With a history of over fifty years, it's high time for the Ethnic Preparatory Education Program to launch National Unified Graduation Examinations for the purpose of promoting the construction, development and reform of the preparatory training institutions. And in the end, ethnic preparatory students will become the biggest beneficiary. 


\section{The OBJECTIVES OF LAUNCHING NATIONAL UNIFIED GRADUATION EXAMINATION}

The chief goals of launching National Unified Graduation Examination for Ethnic Preparatory Education Program involve the following points.

(1) Strengthen supervision, guidance and regulation over the preparatory training institutions from the national-level administrative department, thus promote the sustained, healthy and stable development of preparatory education for minority students.

(2) Establish the social reputation of the ethnic preparatory training institutions as the worthy cradle for fostering the highlevel ethnic minority talents.

(3) Promote the establishment and improvement of an authoritative quality guarantee system for Ethnic Preparatory Education Program, in line with China's national conditions, and with the characteristics of the contemporary age.

(4) Encourage and motivate preparatory training institutions to strive for higher standard through the publicity and propagation on the implementation and results of the National Unified Graduation Examination for Ethnic Preparatory Education Program

(5) Win greater support and better recognition for Ethnic Preparatory Education Program from the public and the whole society.

(6) Promote the research into digital information processing, and computer network technology applied to unified examinations with regard to the text form, content, analysis, and evaluation, which is more cost-saving, transparent and environmentally-friendly.

\section{THE GUIDELINE OF LAUNCHING NATIONAL UNIFIED GRADUATION EXAMINATION}

To sum up, the guiding principle of launching National Unified Graduation Examination for Ethnic Preparatory Education Program is to promote construction, promote reform, and promote management, with construction as the core.

\section{(1) Promote construction}

With National Unified Examination as an opportunity, preparatory training institutions are expected to strengthen the basic constructions involving faculty, curriculum design, teaching materials, management, styles of learning, basic facilities in order to guarantee quality education for ethnic preparatory students, who will turn out to be the high-level talents in remote ethnic areas in the future.

(2) Promote reform

With the supervisory function of the National Unified Examinations, Preparatory training institutions tend to make greater efforts to actively deepen reforms and innovations of different kinds, with regard to renewing education concepts and ideas, optimizing the curriculum structure, perfecting curriculum system, updating teaching content, reforming teaching methods and teaching management, with the aim to cater to the higher requirements from both the administrative departments and the preparatory college students.

\section{(3) Promote management}

In order to achieve desired performance and result in the National Unified Examinations, preparatory training institutions will input more efforts to embark on a track of more standardized, systematized and scientific construction in terms of overall management level and efficient operation.

\section{Potential Problems to Guard Against}

In the process of organizing and launching National Unified Graduation Examination for Ethnic Preparatory Education Program, the following prospective problems may arise and need effective counter-measures.

\section{(1) Utilitarianism}

Too much emphasis might be placed on examination results when preparatory training institutions strive for higher rankings and consequently exert excessive pressure on both their teachers and students.

\section{(2) Disturbance of Normal Curriculum Arrangement}

In order to get desired examination results, some preparatory training institutions may arbitrarily change curriculum arrangement in violation of discipline syllabus, thus interfere with the normal order of teaching and learning.

\section{(3) Fraud and Deception}

Some preparatory training institutions might resort to dishonest or deceptive means such as turning a blind eye to cheating of different types, leaking test materials to the students prior to or in the course of the examinations, so on and so forth.

\section{COUNTERMEASURES}

In view of the potential problems mentioned above, the following measures can be taken.

\section{(1) Enhance transparency}

In the principle of being open, fair and transparent, status quo and basic information about the preparatory training institutions should be open to the society to enable the public to better understand the preparatory training program and National Unified Graduation Examination for Ethnic Preparatory Education Program, for the purpose of accepting the supervision from all walks of life.

\section{(2) Strengthen regular supervision}

Scientific, standard and modern management is the foundation to improving quality and efficiency of teaching 
management. Therefore, functional and administrative departments at different levels should solidify regular monitoring over the routine process and operation of the preparatory training institutions in order to fulfill teaching quality control system and supervise learning environment construction of preparatory courses.

\section{(3) Reward the good and punish the bad}

The routine and day-to-day operation of the preparatory training institutions should be closely linked to the their interests, in terms of government funding, enrollment quota allocation, school ranking, and preferential policy, etc.. Tangible and intangible rewards should be offered to outstanding achievers while the institutions that are not up to the standard should be given warnings, disciplinary punishment and a fix time limit for rectification, even cancellation of enrollment eligibility

\section{(4) Crack down on fraud}

Once verified, all the fraudulent conducts prior to, during or after the National Unified Examinations must be given severe disciplinary punishment to establish the credibility of the examination system.

\section{QUESTIONNAIRE SURVEY ON THE IDENTIFICATION OF NATIONAL UNIFIED GRADUATION EXAMINATION}

In order to know the students' and faculty's attitude to and identification with National Unified Graduation Examination for Ethnic Preparatory Education Program, we have conducted a questionnaire survey in four preparatory training institutions that provide preparatory training to ethnic preparatory students from different academic levels, nationalities, regions and cultural backgrounds. In total, 936 students from both oneyear training program and two-year training program gave responses to our questionnaire, with 914 valid papers collected We also handed out a questionnaire to faculties from the four training institutions, and collected 48 valid papers. The collected statistics from some of the questions are illustrated below.

TABLE I. INSTITUTIONS AND STUDENT RESPONDENTS

\begin{tabular}{|c|c|c|c|c|c|}
\hline Ins. & $\begin{array}{c}\text { Institution } \\
\mathbf{1}\end{array}$ & $\begin{array}{c}\text { Institution } \\
\mathbf{2}\end{array}$ & $\begin{array}{c}\text { Institution } \\
\mathbf{3}\end{array}$ & $\begin{array}{c}\text { Institution } \\
\mathbf{4}\end{array}$ & Total \\
\hline $\begin{array}{c}\text { One-year } \\
\text { students }\end{array}$ & 308 & 106 & 94 & 71 & 579 \\
\hline $\begin{array}{c}\text { Two-year } \\
\text { students }\end{array}$ & 149 & 108 & 52 & 26 & 335 \\
\hline Total & 457 & 214 & 146 & 97 & 914 \\
\hline
\end{tabular}

\section{Question on the identification for the students}

Will you make greater effort in academic work if National Unified Graduation Examination for Ethnic Preparatory Education Program is launched?
TABLE II. RESPONSE TO QUESTION 1

\begin{tabular}{|c|c|c|c|}
\hline Choice & $\mathbf{1 .}$ & $\mathbf{2 .}$ & $\mathbf{3 .}$ \\
statistics & No & Not Certain & Yes \\
\hline Frequency (person) & 45 & 217 & 652 \\
\hline Percentage & $4.9 \%$ & $23.8 \%$ & $71.3 \%$ \\
\hline
\end{tabular}

Conclusion:

1) As high as $71.3 \%$ respondents make an affirmative choice, which can be interpreted as a recognition of the motivational effect of National Unified Graduation Examination. Only about $5 \%$ of the respondents deny the positive wash-back effect from the Unified examinations.

A further analysis is made to test whether students with different academic proficiency and performances show a significant difference in the acceptance of the motivational effect of National Unified Examinations. We chose 50 students at the top of the academic performance list and another 50 students from the bottom of the academic performance list in order to make a comparative study between top achievers and weak achievers in terms of academic achievements. The collected data are as follows.

TABLE III. MEAN AND STD. D COMPARISON

\begin{tabular}{|c|c|c|}
\hline Group & Group of top achievers & Group of low achievers \\
\hline Mean & 2.785 & 2.658 \\
\hline Std. Deviation & .4703 & .4801 \\
\hline
\end{tabular}

TABLE IV. INDEPENDENT-SAMPLE T TEST

\begin{tabular}{|c|c|c|c|c|c|c|c|c|c|}
\hline & \multicolumn{2}{|c|}{$\begin{array}{c}\text { Levene's Test } \\
\text { for } \\
\text { Equality of } \\
\text { Variances } \\
\end{array}$} & \multicolumn{7}{|c|}{ T-test Equality of Means } \\
\hline & \multirow[t]{2}{*}{$\mathbf{F}$} & \multirow[t]{2}{*}{ Sig. } & \multirow[t]{2}{*}{$\mathbf{t}$} & \multirow[t]{2}{*}{ df } & \multirow[t]{2}{*}{$\begin{array}{c}\text { Sig. } \\
2- \\
\text { tailed }\end{array}$} & \multirow[t]{2}{*}{$\begin{array}{l}\text { Mean } \\
\text { Differ- } \\
\text { ence }\end{array}$} & \multirow{2}{*}{$\begin{array}{l}\text { Std. } \\
\text { Error } \\
\text { Differ } \\
\text {-ence }\end{array}$} & \multicolumn{2}{|c|}{$\begin{array}{l}\text { 95\% confidence of } \\
\text { Interval of the } \\
\text { Difference }\end{array}$} \\
\hline & & & & & & & & Lower & Upper \\
\hline $\begin{array}{l}012 \text { Equal } \\
\text { variances } \\
\text { assumed }\end{array}$ & 3.592 & .062 & -1.219 & 81 & .226 & .12718 & $\begin{array}{c}.1043 \\
3\end{array}$ & -.33476 & .08040 \\
\hline $\begin{array}{l}\text { Equal } \\
\text { variances } \\
\text { not } \\
\text { assumed }\end{array}$ & & & -1.219 & $\begin{array}{c}80.83 \\
8\end{array}$ & .226 & .12718 & $\begin{array}{c}.1043 \\
5\end{array}$ & -33481 & 08046 \\
\hline
\end{tabular}

Conclusion:

There is no significant difference between the two groups in their identification of the motivational effect of National Unified Graduation Examination. In other words, both high achievers and low achievers identify with the wash-back effect of National Unified Graduation Examination for Ethnic Preparatory Education Program. Namely, with the launching of the national unified examinations, they will work harder. 


\section{Questions on the identification for the teachers}

Do you identify with the following opinions? Please choose No.1 to No.5 for each opinion to express your degree of identification.

\section{Totally disagree}

\section{Partially disagree}

\section{Not certain}

\section{Partially agree}

\section{Completely agree}

Q1. National Unified Graduation Examination for Ethnic Preparatory Education Program is necessary.

Q2. National Unified Graduation Examination for Ethnic Preparatory Education Program will effectively guide, monitor and administer ethnic preparatory education program.

Q3. National Unified Graduation Examination for Ethnic Preparatory Education Program can evaluate whether or not students meet curriculum requirement.

Q4. National Unified Graduation Examination for Ethnic Preparatory Education Program can evaluate preparatory training institutions' teaching management.

Q5. National Unified Graduation Examination for Ethnic Preparatory Education Program is conducive to guiding the teachers to teach by complying with course syllabus.

Q6. National Unified Graduation Examination for Ethnic Preparatory Education Program can provide constructive and reliable references for follow-up improvement.

TABLE V. PERCENTAge of Teachers' ResPondence

\begin{tabular}{|c|c|c|c|c|c|}
\hline Question & $\mathbf{1}$ & $\mathbf{2}$ & $\mathbf{3}$ & $\mathbf{4}$ & \\
\hline $\mathbf{Q 1}$ & $0 \%$ & $8.3 \%$ & $12.5 \%$ & $29.19 \%$ & $50 \%$ \\
\hline $\mathbf{Q 2}$ & $8.3 \%$ & $25 \%$ & $12.5 \%$ & $33.33 \%$ & $20.83 \%$ \\
\hline $\mathbf{Q 3}$ & $4.17 \%$ & $20.83 \%$ & $12.5 \%$ & $41.67 \%$ & $20.83 \%$ \\
\hline Q4 & $4.17 \%$ & $12.5 \%$ & $16.67 \%$ & $50 \%$ & $16.67 \%$ \\
\hline Q5 & $0 \%$ & $12.5 \%$ & $20.83 \%$ & $50 \%$ & $16.67 \%$ \\
\hline Q6 & $0 \%$ & $16.67 \%$ & $12.5 \%$ & $45.83 \%$ & $25 \%$ \\
\hline Mean & $2.78 \%$ & $15.97 \%$ & $14.587 \%$ & $41.67 \%$ & $25 \%$ \\
\hline
\end{tabular}

\section{Conclusion:}

1) A majority of the teachers surveyed identify with the necessity, significance and positive roles of launching National Unified Graduation Examination for Ethnic Preparatory Education Program. Of the six questions, the percentages of choosing 'partially agree' and 'completely agree' are all over $65 \%$.

2) For Question 1, concerning the necessity of launching National Unified Graduation Examination for Ethnic Preparatory Education Program, the percentage of choosing 'partially agree' and 'completely agree' is as high as $79 \%$.

3) Those who take a negative attitude to the necessity, significance and positive roles of launching National Unified Graduation Examination for Ethnic Preparatory Education Program only account for less than $20 \%$.

\section{CONCLUDING REMARKS}

The necessity and urgency of launching National Unified Graduation Examination for Ethnic Preparatory Education Program is self-evident and, based on the questionnaire survey result, is widely recognized by preparatory students and teachers as well, which is both a challenge and a motivational force for all the preparatory training institutions. And more importantly, it will provide a good opportunity for all the departments concerned to accelerate construction, deepen reform, increase investment in preparatory education, and improve the quality of ethnic preparatory education

\section{REFERENCES}

[1] Liu. Juesheng, "The approaches to th problems in high school proficiency test, " Shanghai Research on Education, Shanghai, Vol.3, 2010, pp. 39-42

[2] Qi. Tian, "The problems and reform suggestions for high school proficiency test," Educational Practice and Research, Shijiazhuang, Vol. 10-B, 2012, pp.220-222

[3] Zhou. Ji, "Teaching evaluation is a key to improving the quality of Education," Chinese University Education, Beijing, Vol.5, 2006, pp. 4-8

[4] Huang. Guangyang, "Reflections on Teaching Evaluation and Construction of Higher Education," Journal of Fujian Normal University (PHILOSOPHY AND SOCIAL SCIENCE EDITION), Fuzhou, Vol.2, 2006, pp. 147-150

[5] Yang. Fan, "Comparison of high school graduation examination system and academic proficiency examination system," Educational measurement and evaluation, Changsha, vol. 4, 2009, pp. 45-47

[6] Yang. Xiangdong, "A comparative study on senior high school proficiency tests," Global Education, Shanghai, Vol 4, 2010, pp. 5-8 